\title{
Petrology and geochemistry of the eastern Australian leucitites
}

\author{
ANTHONY W LANATI ${ }^{1,2}$, JOSHUA J SHEA ${ }^{1}$ AND \\ STEPHEN F. FOLEY ${ }^{1}$
}

\author{
${ }^{1}$ Macquarie University \\ ${ }^{2}$ Universität Münster \\ Presenting Author: anthony.lanati@mq.edu.au
}

The eastern Australian Leucitite suite lies on the $700 \mathrm{~km}$-long southern portion of the world's longest continental hotspot track, the Cosgrove track [1], which extends over 2,000 km from Victoria to Queensland. The northern section of the track is composed of large-volume basaltic central volcanoes with welldefined vents forming large volcanic complexes containing felsic flows and intrusions [2]. In contrast, the leucitites occur exclusively as mafic potassium-rich provinces with low-volume expressions on the order of hundreds of metres to a few kilometres. Davies et al. [1] illustrate that leucitite provinces in eastern Australia are restricted to areas where the lithosphere is thicker than $120 \mathrm{~km}$, whereas tholeiites, alkali basalts and basanites are restricted to thinner lithosphere, suggesting the lithosphere-asthenosphere boundary may have a strong influence on melt composition and subsequently, petrology.

Non-systematic descriptions of some occurrences in the 1970 's and 80's have not been updated by modern methods. However, the textural and chemical definitions of exotic alkalinemelts such as leucitites are evolving constantly [3]. We have undertaken a systematic re-evaluation of the eastern Australian leucitite suite with the aim of updating geochemical data and petrological classifications and descriptions of all known occurrences using modern analytical methods and classification schemes.

Here, we present results of newly acquired major and trace element data for whole-rock (WR) and mineral analyses. Our WR data shows the leucitites are chemically variable, but exceptionally enriched in potassium, with high $\mathrm{K}_{2} \mathrm{O} / \mathrm{Na}_{2} \mathrm{O}$ and $\mathrm{MgO}\left(\mathrm{K}_{2} \mathrm{O} 1.2-7.4 \mathrm{wt} \% ; \mathrm{K}_{2} \mathrm{O} / \mathrm{Na}_{2} \mathrm{O} 0.3-7.8\right.$, and $\mathrm{MgO} 7-16$ $\mathrm{wt} \%$ ). Most occurrences are porphyritic with olivine and/or phlogopite phenocrysts. High $\mathrm{K}_{2} \mathrm{O}$ concentrations are attributed to the abundance of leucite in the aphanitic groundmass and to variable amounts of phenocrystic phlogopite and K-richterite between provinces, with these hydrous minerals explaining loss on ignition measurements up to $4.8 \mathrm{wt} \%$. This new data helps inform interpretations of melt generation and mantle source mineralogy in the light of suggestions of a highly heterogeneous metasomatised mantle beneath eastern Australia [2].

[1] Davies et al. (2015) Nature 525, 511-514;

[2] Shea and Foley (2019) Minerals 9, 546;

[3] Mitchell (2021) Encyclopedia of Geology, 215-239 